\title{
ÉLELMISZERJELÖLÉS JELENTŐSÉGE A VIDÉKI ÉLELMISZERELŐÁLLÍTÁSBAN ${ }^{1}$ \\ IMPORTANCE OF FOOD MARKING IN RURAL FOOD PRODUCTION
}

\author{
Nagyné Pércsi Kinga
}

\author{
egyetemi docens \\ Szent István Egyetem, Gazdaság- és Társadalomtudományi Kar \\ E-mail: nagyne.pecsi.kinga@gtk.szie.hu
}

\section{Összefoglalás}

Az élelmiszerek címkéjén szereplő jelölési információknak fontos szerepe van a vásárlási döntések meghozatalában. Ugyanakkor a fogyasztók más-más élelmiszer összetevőket tartanak veszélyesnek, illetve fontosnak. Előfordul, hogy bonyolultnak tartják a címkén megjelenő információkat, illetve elvesznek a jelölések és védjegyek rengetegében. A helyi élelmiszer termékek és a bioélelmiszerek esetén az is megfigyelhető, hogy a közvetlen termelöi fogyasztói kapcsolat helyettesíti az élelmiszercímkét és a tanúsító védjegyet. Ilyen esetekben jelentősége kevésbé fontos. Vannak olyan kutatások, melyek szerint a fogyasztók elsősorban akkor vizsgálják meg az élelmiszer jelölését, a címkén szereplő információkat, ha valamire allergiásak, vegetáriánus életmódot folytatnak, vagy vallási okok miatt kíváncsiak az összetevőkre (Bandara et. al, 2016). Mindezek alapján érdemes tehát megvizsgálni a kistermelői termékekre, ezen belül is az ökológiai élelmiszerekre vonatkozó jelölési szabályokat, valamint a címke szerepét a vásárlói döntéshozatalban. A cikk célja a fentieknek megfelelően annak vizsgálata, hogy mennyire fontosak a közvetlen termelői-fogyasztói kapcsolatok a bioélelmiszereket fogyasztók körében, illetve helyettesíti-e ez a kapcsolat az élelmiszercímkét? További érdekes, címkézéshez kapcsolódó kérdés, hogy milyen összetevőket tartanak veszélyesnek a bioélelmiszereket fogyasztók? A kutatás módszere a szakirodalmi vizsgálat mellett a személyes megkérdezés és egy önkényesen kiválasztott minta papír alapú kérdőíves vizsgálata volt.

\begin{abstract}
The information on food label has an important role in decision making process of purchase. The consumers find different food components dangerous and important. It often comes for that they find the food label information complicated and they are lost in the abundance of labels. In the case of local and organic food it can be observed that the direct consumer - producer relations can substitute the quality proving labels and food marks, their importance is less in such cases. Researches exist according to which the consumers investigate the food labels only in that case if they are affected by food allergy, or they are vegetarian or they would like to know the list of components because of religious causes (Bandara et al, 2016). On the basis of the aforementioned it is worth to introduce the labelling rules and to analyse the role of food labels in decision process of purchase. The aim of the article is to analyse the importance of the direct producer-consumer relations in the circle of organic consumers and that if this relation substitutes the information on food label? Further interesting question relating to labelling is which components of food are held to be dangerous by the organic food consumers. Beside the literature review the method of the research is the personal interviews and the paper based survey on arbitrarily selected sample.
\end{abstract}

\footnotetext{
${ }^{1}$ Ez a tanulmány a Nemzeti Közszolgálati Egyetem és partner intézményei által megvalósított KÖFOP-2.1.2VEKOP-15-2016-00001 “A jó kormányzást megalapozó közszolgálat-fejlesztés” projekt keretében készült.
} 
Kulcsszavak: védjegy, élelmiszercímke, összetevők, ökológiai, biztonság, bizalom

JEL besorolás: Q18, R19, M31

LCC: $S 1$

\section{Bevezetés}

Rácz (2013) kutatásai alapján megállapítható, hogy a Magyar termék és Biotermék védjegyeket észlelő fogyasztók előnyben részesítik a közvetlen értékesítésből származó élelmiszereket. Ismert védjegy továbbá a Hungarikum védjegy bár itt egyéb értékesítési formák dominálnak. (Kassai et al, 2016). Az egyre igényesebb fogyasztó a minőség mellett a vásárlás átláthatóságát és biztonságát is igényli. Lewis és Bridger (2001) is arra a következtetésre jutott, hogy a fogyasztó döntéshozatalában a bizalom kiemelkedően fontos szempont. A hagyományos táplálkozás veszélyeinek felismerése és az élelmiszerbotrányok miatt a bizalom egyre nagyobb szerephez jut az élelmiszerek kiválasztása során. A bizalom lényege ebben az aspektusban, hogy általa leegyszerüsíthető a vásárlói döntés (Brávácz, 2015).

Haas et al (2014) arra a megállapításra jutott, hogy hiába az eltérö értékesítési csatorna, címkézés, jelölés, árképzés az ökológiai és a helyi élelmiszerek egymás versenytársai, helyettesítöi az amerikai élelmiszerpiacokon (Szente, 2015). Éppen ezért mivel a helyi termékek speciális esetét képezik az ökológiai élelmiszerek, ezek címkézési, jelölési követelményeit, elöírásait is érdemes áttekinteni, valamint megvizsgálni, hogy a fogyasztók e termékek esetében milyen információt tartanak fontosnak a terméken.

Ai és Swee (2001) szerint az észlelést befolyásolja, hogy a fogyasztó új, vagy már ismert információval találkozik. Az ismeretlen információ esetén előfordulhat, hogy a fogyasztó nem képes ahhoz jelentést társítani, így nem vonja be a vásárlási döntési folyamatba (Lehota - Rácz, 2013). Az újdonságtartalmon kívül fontos szerepet kap a csomagoláson feltüntetett információk mennyisége és minősége, vagyis a jelölések száma és hasznossága. A jó minőségű információk növelik a fogyasztó bizalmát a termékkel kapcsolatban, így képesek jelentős mértékben befolyásolni a vásárlási döntést. Az elöbbiek mellett fontos, hogy az információ a fogyasztó számára hiteles legyen, a jelölések, tanúsító szervezetek sokasága ugyanis összezavarja (Loureiro et al. 2002, Sabbe et al., 2009 in Lehota - Rácz, 2013).

Lehota és Rácz (2013) vizsgálatai alapján arra a megállapításra jutott, hogy nélkülözhetetlen a fogyasztók jelölésekkel kapcsolatos ismereteinek bővítése az értékrendnek megfelelő vásárlási döntés érdekében. Még a leginkább elkötelezett fogyasztók esetén is megfigyeltek némi fogalmi bizonytalanságot (pl. öko, natúr termékek), valamint azt, hogy ezek a fogyasztók az egészséges életstílus követelményeit főként a diétás étrend kialakításával párosítják, amelyek a valóságban nem értelmezhetők szinonim fogalmakként.

Az élelmiszerekkel kapcsolatos tájékoztatásért elsődlegesen felelős élelmiszer-vállalkozó az a vállalkozó, akinek neve vagy cégneve alatt az élelmiszert forgalomba hozzák, vagy ha ez a vállalkozó nem letelepedett az Unió területén, akkor az élelmiszert az uniós piacra behozó importör. Ugyanakkor a lánc valamennyi tagja felelősséggel tartozik a saját hatáskörén belül a jelölési információk meglétéért és pontosságáért.

\section{Általános jelölési szabályok}

Az 1169/2011/EU rendelet szerint az élelmiszer-vállalkozóknak az ellenőrzésük alá tartozó vállalkozásokban biztosítaniuk kell, hogy a végső fogyasztónak vagy vendéglátásnak, illetve közétkeztetésnek szánt, nem előre csomagolt élelmiszerek esetében is továbbítsák az 
élelmiszerrel kapcsolatos információkat az élelmiszert átvevő gazdasági szereplőnek, hogy lehetővé váljon a kötelező tájékoztatás ismertetése a végső fogyasztóval. A 36/2014. (XII. 17.) FM rendelet szerint a nem elöre csomagolt élelmiszerek például a következők:

- zsemle, kifli, egyéb péksütemények

- párizsi, sajt, amit a vevő kér és jelenlétében becsomagolnak

- kereskedelmi elörecsomagolt kakaós ostya

- vendéglátás során felkínált ételek.

2015. április 1-jétől a nem előre csomagolt élelmiszer végső fogyasztónak történő értékesítése esetén az eladás helyén jól látható módon fel kell tüntetni például a pultban egy táblán a következő információkat:

1. Élelmiszer neve.

2. Az élelmiszer nevéhez kapcsolódóan fel kell tüntetni:

- „Édesítőszerrel (édesítőszerekkel)”

- „Cukorral (cukrokkal) és édesítőszerrel (édesítőszerekkel)”

3. Narancssárga S (E 110), Kinolinsárga (E 104), Azorubin (E 122), Alluravörös (E 129), Tartrazin (E 102), Neukokcin (E 124) színezékek jelenléte esetén:,,a színezék(ek) megnevezése vagy E-száma, valamint a gyermekek tevékenységére és figyelmére káros hatást gyakorolhat"

A végső fogyasztót kérésére az egyéb jelölési információkról is tájékoztatni kell (pl. összetevőkről, gyártóról, tárolási feltételekről stb.), ennek módja azonban nincs előírva, a tájékoztatás szóban is elegendő. Ha a vevő rákérdez a kiskereskedelmi pultban elhelyezett valamely termék összetevőire, akkor a tájékoztatást a kereskedőnek meg kell adnia. Ahhoz, hogy a kötelező tájékoztatásnak a kereskedő eleget tudjon tenni, a kiskereskedelmi forgalmazásra átadott termékeket a kísérő dokumentumban úgy kell jelölni, mintha csomagolt lenne, vagyis nem elegendő csak az allergéneket, hanem az összetevőket is fel kell tüntetni. Ezt a dokumentumot egyszer is elég megküldeni a kereskedőnek, azonban ha bármilyen változás történik, akkor haladéktalanul újat kell küldeni.

36/2014. (XII. 17.) FM rendelet szerint a végső fogyasztó figyelmét az allergénekre is fel kell hívni. Az allergénre vonatkozó információnak könnyen elérhetőnek kell lennie, és jól látható módon kell megjeleníteni. A tájékoztatást az eladás helyén kell megtenni, például az étlapon, vagy a nem elörecsomagolt élelmiszerek esetében a pultban elhelyezett táblán kell feltüntetni. A tájékoztatás elérhetőségének helyére a végső fogyasztó figyelmét jól olvasható módon, a létesítményben elhelyezett fizikai vagy elektronikus hordozón fel kell hívni, például: " Az allergénekről tájékozódjon a kihelyezett plakáton!". Ugyanakkor szóban is közölhető az allergén információ, ha valamilyen módon felhívják erre a vásárló figyelmét, például: " Az allergénekről tájékozódjon az eladónál!". Ennek azonban feltétele, hogy a létesítményben folyamatosan jelen van az információ átadásáért felelös személy, a fogyasztó, kérésére, az információt haladéktalanul megkapja az élelmiszer átadásának helyén, a vásárlást megelőzően, valamint az információ a létesítményben elérhetô írásos dokumentumon alapul.

2015. július 1-jétől kötelező az élelmiszer-vállalkozónak belső eljárást kell kidolgoznia az allergének jelenlétére vonatkozó szóbeli tájékoztatás megadásának módjáról és ki kell jelölnie a szóbeli tájékoztatás megadásáért felelős személyt. A belső eljárást fizikai vagy elektronikus adathordozón dokumentálni kell és a személyzet, valamint az ellenőrző hatóság számára könnyen elérhetővé kell tenni. A belső eljárásban az oktatásra is ki kell térni, amelyet dokumentumokkal is alá kell támasztani. 
52/2010. (IV. 30.) FVM rendelet alapján, ha a kistermelö csomagoltan értékesíti a termékét a gazdaság helyén, piacon, vásáron, rendezvényen, engedélyezett ideiglenes árusító helyen, valamint házhozszállítással, akkor a csomagoláson feltüntetnie a kistermelő nevét, címét vagy a gazdaság helyének címét, a termék nevét, a lejárati dátumát, fogyaszthatósági idő esetén tárolási hőmérsékletét, a termék tömegét, kivéve, ha a kistermelő a vevő jelenlétében méri le.

Ha a kistermelő csomagolatlanul értékesíti termékét, akkor a kihelyezett termék elött fel kell tüntetni a nevét, címét, a gazdaság helyének címét, valamint a termék nevét. A kistermelőkre is vonatkozik az allergénekre vonatkozó tájékoztatási kötelezettség, de nem kell például táblán kiírni, hogy erről kérhetnek tájékoztatást a vevők. Szóban is megadható az allergén információ, ha az információt haladéktalanul megkapja a fogyasztó az élelmiszer átadásának helyén, a vásárlást megelőzően. A tájékoztatásnak nem kell írásos dokumentumon alapulnia, és eljárásrendet sem kell készíteni róla.

1337/2013/EU rendelet alapján 2015. április 1-jétől az előrecsomagolt, végső fogyasztónak szánt, valamint a közétkeztetésben müködő gazdasági szereplönek szánt friss, hütött, vagy fagyasztott sertés-, juh-, kecske-, és baromfihús esetében fel kell tüntetni az állattartás helyét, a vágás helyét, valamint a hús azonosító tételszámát. Az állattartás helyének meghatározása konkrét elöírások szerint történik, állatfajonként (sertés, juh és kecse, valamint baromfi) eltérö módon.

Ha a húst vagy az állatokat az Unióba importálták, akkor a következő jelölést kell alkalmazni:,Az állattartás helye: több Európai Unión kívüli ország” vagy „Az állattartás helye: az Európai Unió több tagállama és több Európai Unión kívüli ország”. Ha hitelt érdemlően bizonyítható az állat nevelésének helye, akkor a tagországokat is fel lehet sorolni. Ha a hús olyan állatból származik, amely egyetlen tagállamban született, nevelkedett és került levágásra, akkor a származás kifejezést is lehet használni: "Származási hely: Magyarország".

A fogyasztónak vagy közétkeztetésben müködő gazdasági szereplőnek szánt, ugyanazon csomagban elhelyezett több, azonos vagy különböző fajból származó húsdarabra a címkén fel kell tüntetni valamennyi faj esetében a megfelelö tagállamok felsorolását, illetve a fogyasztónak vagy a közétkeztetésben müködő gazdasági szereplőnek szállított hús azonosító tételszámát.

A pultba kitett nem elörecsomagolt húsoknál azonban a 1337/2013/EU rendeletben elöírtakat a pultban nem kell feltüntetni.

\section{Ökológiai termékek jelölése}

Az ökológiai termékek jelölésének főbb szabályait a Hungária Öko Garancia (2018) tanúsító szervezet honlapján található információk alapján ismertetem. A vállalkozás által forgalmazott termékekről listát kell vezetni, melyet folyamatosan aktualizálni kell. Kizárólag azokat a termékeket lehet az ökológiai eredetre utaló jelöléssel ellátni és forgalomba hozni, amelyek szerepelnek a vállalkozás részére kiállított érvényes tanúsítványon, azaz amelyeket a vonatkozó jogszabályok szerint és egy elismert ellenőrzőszervezet ellenőrzése mellett állítottak elő. A termékek címkéin (az egyéb jogszabályi kötelezettségeken felül) szerepeltetni kell a termék megnevezését, az elöállító/forgalmazó nevét, címét, az ökológiai eredetre utaló jelölést, valamint az utolsó árumanipulálást (feldolgozást/csomagolást/címkézést) ellenőrző szervezet kódszámát. 
Feldolgozott élelmiszerek esetében a következő három kategóriát különböztetjük meg:

1. Ökológiai jelölés a kereskedelmi megnevezésben, ha a termék föként mezőgazdasági összetevőkből áll, melyek legalább 95\%-a ökológiai, és kizárólag a 889/2008/EK rendelet 27. cikkében, valamint VIII. és IX. mellékletében foglalt nem ökológiai illetve nem mezőgazdasági eredetü összetevőket, adalék- és segédanyagokat tartalmazza, és az ott elöírt korlátozásokat betartották.

2. Ökológiai jelölés kizárólag az összetevők felsorolásában, ha a termék föként mezőgazdasági összetevőkből áll, és kizárólag a 889/2008/EK rendelet 27. cikkében és VIII. mellékletében foglalt nem mezőgazdasági eredetü összetevőket, adalék- és segédanyagokat tartalmazza, és az ott elöírt korlátozásokat betartották.

3. Ökológiai jelölés az összetevők felsorolásában és a kereskedelmi megnevezéssel egy mezőben, ha a fö összetevő halászati vagy vadászati termék, az egyéb mezőgazdasági eredetű összetevők mindegyike ökológiai, a termék föként mezőgazdasági összetevőkből áll, és kizárólag a 889/2008/EK rendelet 27. cikkében és VIII. mellékletében foglalt nem mezőgazdasági eredetü összetevőket, adalék- és segédanyagokat tartalmazza.

Az összetevők felsorolásában minden esetben fel kell tüntetni, mely összetevők ökológiai eredetüek. A 2. és 3. pont esetében az ökológiai termelésre vonatkozó hivatkozások kizárólag az ökológiai összetevőkkel kapcsolatban jelenhetnek meg, és az összetevők felsorolásában fel kell tüntetni az ökológiai összetevők teljes százalékos arányát a mezőgazdasági eredetü összetevők teljes mennyiségéhez képest. Mindezeket pedig az összetevők felsorolásában szereplő egyéb jelzésekkel megegyező színben, méretben és betütípussal kell feltüntetni.

Az ökológiai státusszal tanúsított termékeken (1. kategória) 2010. július 1-ét követően az EU ökológiai logóját is kötelezően szerepeltetni kell. Ezeken a termékeken feltüntethető továbbá a tanúsító szervezet logója is.

Érdekes ugyanakkor, hogy a bio termékek ellenőrző szervezetei által kiadott címke ismertsége csekély, és a fogyasztók csupán 10,2\%-át befolyásolja (Szakály - Szigeti, 2012 in Szakály Szente, szerk., 2012).

\section{Módszer}

A szakirodalom és a vonatkozó jogi anyag feldolgozása alapján ismertetem a kistermelői élelmiszerjelölési elöŕrásokat, valamint az ökológiai gazdálkodás követelményeinek megfelelően előállított élelmiszerek jelölési szabályait, előírásait. Az élelmiszerjelölési jogszabályok feldolgozásához a Nemzeti Élelmiszerlánc-biztonsági Hivatal által oktatási célra készített, tájékoztató anyagokat is felhasználtam (NÉBIH, 2015). Az ökológiai termékek jelölési követelményeinek fogyasztók általi megítélését, a fogyasztók által fontosnak tartott követelményeket, információkat az ökopiaci fogyasztók felmérésével és véleményével támasztom alá. 32 ökopiaci fogyasztóval készült kérdőíves vizsgálat ez év februárjában a legnagyobb hazai ökopiacon, a Biokultúra Szövetség ökopiacán, melyet a Biokontroll Hungária Kft. tanúsító szervezet ellenőriz. A kérdőívet személyesen megkérdezés útján töltöttük ki, így a megkérdezetteknek lehetőségük volt egy-egy kérdés kapcsán a személyes véleményük kifejtésére, melyet feljegyeztünk. Az alkalmazott kérdőív 16, többségében zárt kérdést tartalmazott, melyek a fogyasztó táplálkozási szokásaira, fogyasztói magatartására, attitüdjére, beszerzési csatorna választására és demográfiai jellemzőire kérdezett rá. A megkérdezetteknek, mint ahogy említettem lehetőségük volt az személyes véleményüket, észrevételeiket szabadon kifejteni. Az előzőeken kívül, a Szent István Egyetem „Élelmiszer-biztonság, minőségbiztosítás”, valamint a „Higiénia a vendéglátásban” c. kurzusainak harmadéves 
hallgatói segítségével 842 kérdőívet gyüjtöttem össze a megadott határidőig. A hallgatók feladata a tágabb család, szülők, nagyszülők, nagybácsik, nagynénik, rokonok megkérdezése volt. Ezeket a kérdőíveket is feldolgoztam az elemzésben. Az összes kérdőívböl a biopiacon vásárló minta elemszáma összesen 102 amelybe beletartozik a közvetlenül, a Biokultúra Biopiacon személyesen megkérdezett 32 fő is. A bioélelmiszer fogyasztók száma természetesen ennél több, ők föként speciális boltban és kiskereskedelmi láncokban vásárolnak bioélelmiszert. A vizsgálat hipotézisei, hogy az élelmiszercímke információit helyettesítik a közvetlen termelöi és fogyasztói kapcsolatok, valamint hogy a hazai bioélelmiszer fogyasztók más európai országokéihoz hasonlóan elsősorban vegyszermentessége miatt fogyasztják az ökoélelmiszert, amire az ökovédjegy a garancia.

\section{Eredmények}

A biopiacon vásárlók 67\%-a nő, 33\%-a férfi. Talán nem meglepő, hogy egy 2014 nyarán készült a teljes lakosságra kiterjedő reprezentatív kutatás alapján a nők átlag feletti arányban válaszolták, hogy ők maguk felelnek a bevásárlásért. Ugyanezen felmérés szerint a nők az átlagosnál nagyobb figyelmet szentelnek az élelmiszerek egészségre gyakorolt hatásának is (Jakopánecz, 2015).

A megkérdezettek 58\%-a budapesti lakos, ez a közvetlen budapesti ökopiaci felmérésböl is következik, hiszen ott kevés kivételtől eltekintve mindenki budapesti lakos volt. A megkérdezettek 61\%-a felsőfokú végzettségü, és mint ahogy az a korábbi felmérések alapján várható volt $87 \%$-uk nyilatkozott úgy, hogy családja átlagos, vagy annál magasabb egy före jutó jövedelemmel rendelkezik. Egy 2012-ben készült Medián felmérés szerint is a vegyszermentes egészséges és lehetőleg szezonális termékeket a magasabb iskolai végzettséggel rendelkezők preferálják (Medián, 2013). Egy másik reprezentatív vizsgálat (Szente, 2015) alapján megállapítható, hogy azok, akik ökológiai termékeket vásárolnak döntően nők, felsőfokú végzettséggel rendelkeznek, szellemi foglalkozásúak és vagy átlagos, vagy annál magasabb jövedelemmel rendelkeznek.

Felmérésünk egyik érdekes és témához kapcsolódó megállapítása, miszerint az ökológiai piaci fogyasztók élelmiszerbiztonsági kérdésekben igen felkészültnek és tájékozottnak érzik magukat (1. ábra). Saját magukat kellett értékelniük ezen a téren 1-10-ig adható pontokkal, és mint ahogy az az ábrán látható senki nem adott 4-nél rosszabb pontot magának. A legtöbben 8 ponttal értékelték tudásuk, az átlag pedig 7,1 volt, ami magas szintü felkészültséget jelez.

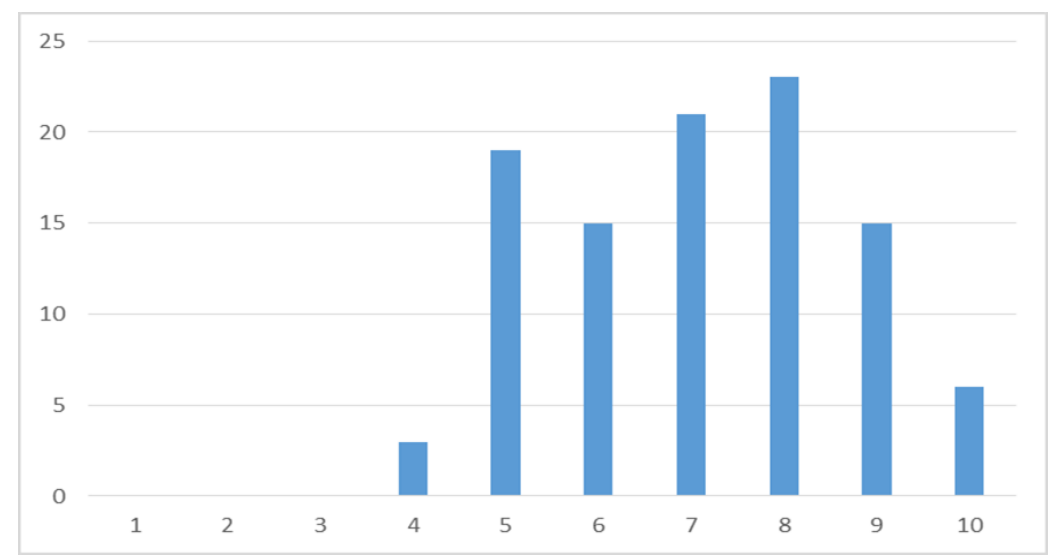

\section{1. ábra.: Az ökopiaci fogyasztók élelmiszerbiztonsági felkészültsége, önértékelés alapján}

Forrás: Saját adatgyüjtés és feldolgozás, 2018

Magyarázat: $N=102$ 
A Budapesti Ökopiacon történt közvetlen megkérdezéses interjú tapasztalatai alapján elmondható, hogy valóban minden megkérdezett tájékozott volt és nem csak az alapvető kérdésekben. Tudták, például hogy vannak kevésbé káros, illetve szükséges adalékanyagok, hogy nem minden édesítőszer káros az egészségre, hogy mi a transz-zsírsav, E-szám. Érdekes az is, hogy sokan említették, hogy nem azért preferálják a hazai termékeket, mert biztonságosabbnak tartják, hanem emocionális okokból. Ezt a 32 meginterjúvolt személyből 24 említette. Sokan azt is tudták, hogy kit büntetett meg a piacon a NÉBIH (9). A legtöbben évek óta járnak már erre a piacra (23), ami lehetőséget ad számukra a hosszú távú termelői-fogyasztói kapcsolatok kialakulására, hiszen a piacon a termelők nagyobb része több, mint 10 éve jelen van. A legtöbb gazdálkodó is itt szerzi be egymástól heti rendszerességgel azokat a termékeket, amelyeket maga nem tud elöállítani.

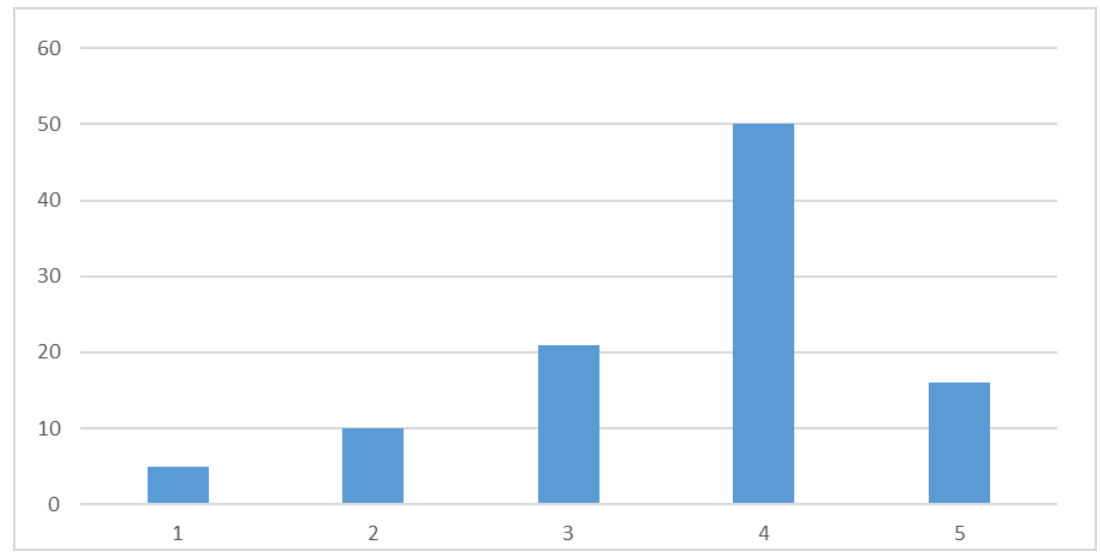

2. ábra: Az élelmiszerbiztonsági helyzet megítélése az ökopiaci fogyasztók szerint ${ }^{2}$

Forrás: Saját adatgyüjtés és feldolgozás, 2018

Magyarázat: $N=102$

Az ökopiaci fogyasztók az élelmiszer-biztonsági helyzetet átlagosan 3,61 pontra értékelték a maximálisan adható 5-böl. Ez azt jelenti, hogy szerintük némileg javult a helyzet az élelmiszerek biztonsága terén az elmúlt években. A legtöbb válaszadó, a megkérdezettek majdnem fele 4 pontot adott (2. ábra).

Az élelmiszer címkéjén feltüntetett adatok közül leginkább befolyásolja az ökopiaci fogyasztók vásárlási döntését az összetevők és az adalékanyagok mennyisége (3. ábra). Legkevésbé a márkanév foglalkoztatja őket, ami az ökológiai élelmiszer sajátossága, hiszen az ökológiai termékek piacán nincsenek erős márkanevek, az egyes márkanevekhez nem tartozik erős marketing tevékenység. Szente (2015) által végzett felmérés szerint a magyar fogyasztó ökológiai élelmiszervásárlási döntéseire legkisebb hatással a reklám, a termék hozzáférhetősége és a gyártó cég neve vannak. Ezt a jelenséget valószínüleg az okozza, hogy a konvencionális termékekhez képest az ökológiai termékeket különlegesnek érzik a fogyasztók, amelyeket nem azért tesznek a kosarukba, mert látták a reklámokban, másrészt az ökológiai élelmiszer beszerzési helyét tekintve inkább az az elvárásuk, hogy az megbízható legyen. A márkanév kisebb jelentőségét valószínüleg az okozza, hogy nincs széles körben elterjedt és ismert ökológiai márka Magyarországon és a cégek egyike sem törekszik nevének hangsúlyozására. A szerző is arra az eredményre jutott, hogy az ökológiai védjegy csak a döntésbefolyásoló tényezők listájának közepén található, amely egyértelmüen az információ

\footnotetext{
2 1- Jelentősen romlott; 2-Némileg romlott; 3-Nem változott; 4-Nemileg javult; 5-Jelentősen javult.
} 
hiányra utal és felhívja a figyelmet azokra a kezdeményezésekre, amelyek az ökoélelmiszerek egyértelmủ azonosítást kívánják segíteni (Szente, 2015).

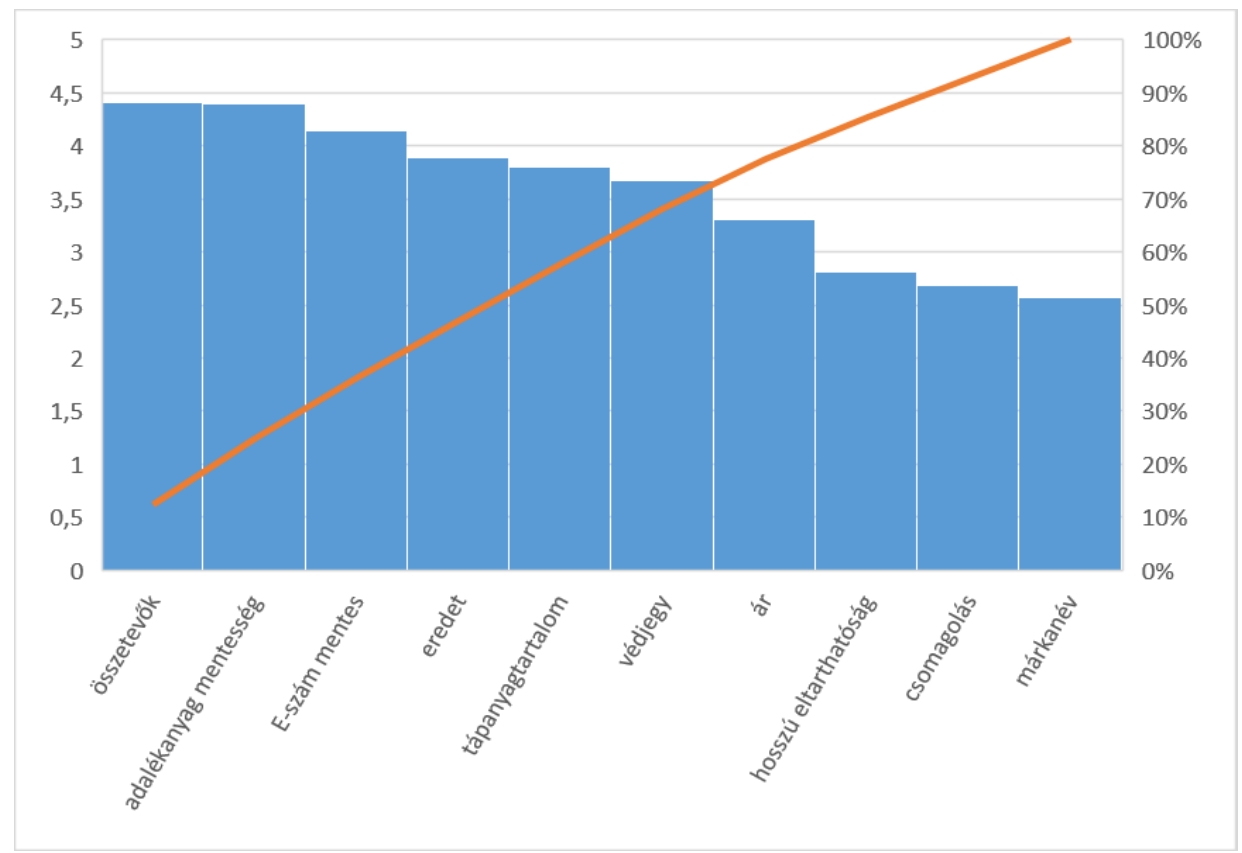

\section{3. ábra: Az élelmiszeren feltüntetett információk fontossága az ökopiaci fogyasztók számára}

Forrás: Saját adatgyüjtés és feldolgozás, 2018

Magyarázat: $N=102$

Jakopánecz (2015) vizsgálatai szerint az átlag hazai fogyasztó megvizsgálja az élelmiszer csomagolását 77,8\%-ban. Átlag feletti arányban vizsgálják meg a megvásárolni kívánt termékek csomagolását az 50 év felettiek, a szellemi dolgozók, a nyugdíjasok és az átlagos jövedelmủek (Jakopánecz, 2015). Elemzése szerint az átlag magyar fogyasztónak viszont a legfontosabb szempont a lejárati idő, a hosszú eltarthatóság és csak ezt követően érdeklik az élelmiszer összetevők. Érdekes, hogy a gyártó neve és a csomagolás kinézete az átlag magyar élelmiszefogyasztó számára is utolsó szempontok. Megállapította továbbá, hogy az élelmiszervásárlás során átlag felett tartják fontosnak a legtöbb szempontot (lejárati idő, a termék összetevői, országeredet (származási ország), a termék tápértéke, a védjegyek, a termék gyártójának neve, a termék csomagolásának kinézete) a nők, az 50 évnél idősebbek, és a nyugdíjasok. (Jakopánecz, 2015).

Az ökopiaci fogyasztók szerint a legveszélyesebb anyag az élelmiszerben a káros szermaradvány tartalom (4. ábra). Ez az élelmiszerválasztást befolyásoló legfontosabb tényezőkkel is összecseng, valamint az ökológiai gazdálkodás élelmiszer-biztonsági követelményeinek is megfelel, hiszen az ökoélelmiszerek legföbb élelmiszer-biztonsági előnye a szermaradvány mentesség. Ezek az élelmiszerek továbbá sokkal kevesebb adalékanyagot tartalmaznak. A génmódosított szervezetektől mentes termelés szintén alapvető követelmény az említett gazdálkodási formánál. Érdekes ugyanakkor, hogy a GMO-összetevők, a tartósítószerek és a penészgomba gyakorlatilag egyformán kockázatos tényezők e szegmens megítélésében. 


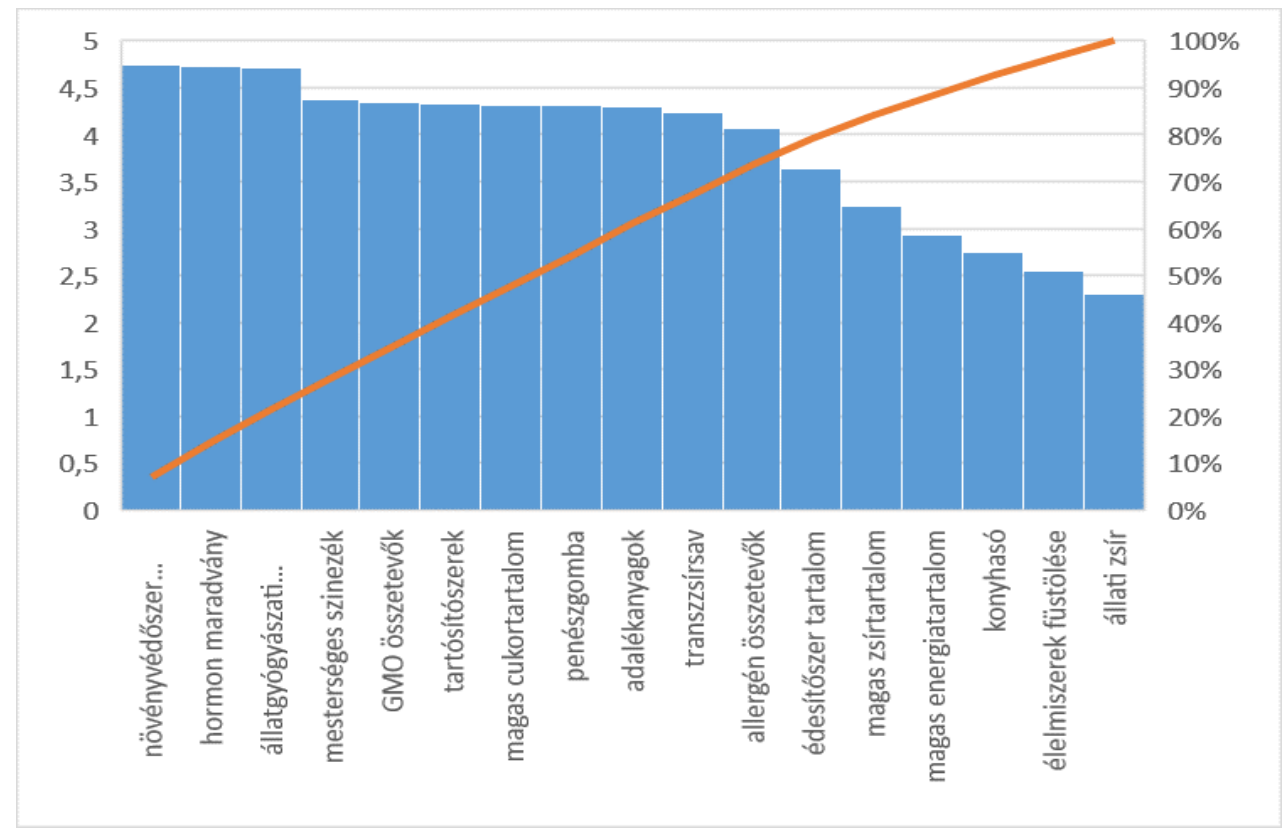

\section{4. ábra: Az ökopiaci fogyasztók által legveszélyesebbnek ítélt összetevők}

Forrás: Saját adatgyüjtés és feldolgozás, 2018

Magyarázat: $N=102$

\section{Következtetések}

A Budapesti Ökopiacon készült közvetlen megkérdezéssel történt vizsgálatból egyértelmüen kiderült, hogy az ökopiaci fogyasztók is bizalmatlanok az ökopiaci árusítókkal szemben, néhány terméknél, különösen a zöldség, gyümölcs, méz, tojás esetében, de a hús- és tejtermékek beszerzésénél is igyekeznek ugyan attól a termelőtől vásárolni, akivel közvetlen kapcsolatot alakítanak ki. A legtöbben hosszú évek óta egy termelőtől szerzik be az előbbiekben felsorolt élelmiszerféleségeket. A termelöi-fogyasztói kapcsolatok fontosságát támasztja alá a felmért ökopiaci fogyasztók hozzáállása is, vagyis az, hogy nagyon fontos számukra az élelmiszer beszerzési helyének megválasztása. Tehát nem a márkanév és a védjegy dominál a döntéseikben, hanem az ökológiai élelmiszer beszerzési helyének megbízhatósága. Tehát a vizsgálat hipotézisei közül az első miszerint a termelői és fogyasztói kapcsolatok helyettesítik a címke információit igazolódott a vizsgálat eredménye alapján, viszont a második, miszerint a vegyszermentességre a védjegy a garancia, nem nyert alátámasztást, sőt ellenkezőleg, sokkal hangsúlyosabb a hosszú távú kapcsolat a termelővel.

Az élelmiszer címkéjén feltüntetett adatok közül leginkább befolyásolja az ökopiaci fogyasztók vásárlási döntését az összetevők és az adalékanyagok mennyisége. Legkevésbé a márkanév foglalkoztatja őket, ami az ökológiai élelmiszer sajátossága, hiszen az ökológiai termékek piacán nincsenek erős márkanevek, az egyes márkanevekhez nem tartozik erős marketing tevékenység.

Szente (2015) is arra az eredményre jutott, hogy az ökológiai védjegy csak a döntésbefolyásoló tényezők listájának közepén található, amely egyértelműen az információ hiányra utal és felhívja a figyelmet azokra a kezdeményezésekre, amelyek az ökoélelmiszerek egyértelmü azonosítást kívánják segíteni.

Az általunk végzett kérdőíves kutatás is alátámasztja a vonatkozó szakirodalom megállapítását, miszerint a legfőbb élelmiszervásárlást motiváló tényező az ökopiaci fogyasztóknál az 
egészségre gyakorolt kedvező hatás és legveszélyesebb tényezőnek az élelmiszerek szermaradvány tartalmát ítélték.

Jakopánecz (2015) szerint a hazai élelmiszerfogyasztók az elmúlt három évben egészségesebb, több hazai eredetü, és kevesebb élelmiszert vásárolnak. Tehát az egészségtudatosság erősödése és az élelmiszerbiztonsági követelmények erősödése általános jellemzője a hazai piacnak. Ezt más vizsgálatok is alátámasztják (International Markets Bureau Canada, 2013). Ez a tendencia további lehetőségeket rejt a helyi kistermelői élelmiszerek, ezen belül különösen az ökológiai gazdálkodásból származó élelmiszerek számára. A jövőben érdemes termelői oldalról is megvizsgálni a védjegyek szerepét és a termelői-fogyasztói kapcsolatok fontosságát, hiszen amennyiben az ökoélelmiszer elhagyja a helyi, illetve a termelöi piacot a védjegy szerepe és az általa közvetített információ tartalom szerepe megnő a fogyasztó vásárlási döntéseiben. A védjegyhez kapcsolódó bizalom erösítése is további feladatként merül fel.

\section{Irodalomjegyzék}

1. Ai, C. L., Swee, H. A. (2001): He who knows most says least, but says best: An information overload perspective. in: Tidwell P. M., Muller T. E. (eds.): Asia Pacific Advances. Consumer Research. Vol. 4, Provo, UT : Association for Consumer Research, 60-66. p. in Lehota - Rácz (2013)

2. Bandara, B. E. S., De Silva, D. A. M., Maduwanthi, B.C.H., Warunasinghe, W.A.A. I. (2016): Impact of food labeling information on consumer purchasing decision: with special reference to faculty of Agricultural Sciences, International Conference of Sabaragamuwa University of Sri Lanka 2015 (ICSUSL 2015), Procedia Food Science 6 ( 2016$) 309-313$

3. Brávácz I. (2015): Az élelmiszerfogyasztói magatartás két dimenziója: az egészség- és a környezettudatosság, PhD Értekezés, SZIE, Gödöllő, 2015

4. Haas, R, Sterns, J., Meixner, O.; Nyob, D-I.; Traar V. Do US Consumers' Perceive Local and Organic Food Differently? An Analysis Based on Means-End Chain Analysis and Word Association. Int. J. Food System Dynamics 2013, 4(3): 214-226.

5. Hungária Öko Garancia (2018): Ökológiai termékek kereskedelme. Letöltés dátuma: 2018.03.24. http://www.okogarancia.hu/pdf/INFO-06_ivrev03_17-05-18_ker.pdf

6. InternationalMarketsBureau Canada (2013): The Hungarian ConsumerBehaviour, Attitudes andPerceptions TowardFood Products, Market Analysis Report, January 2013

7. Jakopánecz, E. (2015): Élelmiszer-vásárlási tudatosságés fogyasztói ellenállásra való hajlandósága magyar felnőtt lakosság körében. Dr. Törőcsik Marketing InspirációFogyasztói Magatartás Kutató Intézet, WHO Egészség Világnap, Élelmiszerbiztonság konferencia, 2017. április 7.

8. Kassai, Zs., Káposzta, J., Ritter, K., Dávid, L., Nagy, H., Farkas, T. (2016): The territorial significance of food hungaricums: the case of pálinka. Romanian Journal of Regional Sciences 2016. Vol.10. No. 2. ISSN 1843-8520 pp. 64.84. http://www.rrsa.ro/rjrs/rjrs.swf

9. Lehota, J., Rácz, G. (2013): Az élelmiszer-információk vásárlási döntést befolyásoló szerepének változása a fenntarthatóság trendjének hatására. http://kgk.sze.hu/images/dokumentumok/kautzkiadvany2013/marketing/lehota_racz.p df

10. Loureiro, M., L., Mccluskey, J., J., Mittelhammer, R., C. (2002): Will consumers pay a premium for eco-labeled apples?. Journal of Consumer Affair. 2002/8. 203-219. p., in Lehota - Rácz (2013)

11. Medián (2013) Attitudes towards the social effects of food purchasing. Report for ESSRG. Manuscript in Hungarian in Kneafsey et. al., 2013 
12. NÉBIH (2015): Az élelmiszerjelöléssel kapcsolatos új elöírások, a gyakorlati megvalósulásuk tapasztalatai. Letöltés dátuma: 2018.03.24. http://www.nak.hu/images/Kamara/Letoltheto/NAK_orszagjaras_jelolesi_eload\%C3\% A1s_teljes_PDF.pdf

13. Sabbe, S, Verbeke, W., Van Damme, P. (2009): Perceived Motives, Barriers and Role of Labelling Information on Tropical Fruit Consumption: Exploratory Findings. Journal of Food Products Marketing. 15(2). 119-138.p. in Lehota - Rácz (2013)

14. Szakály, Z., Szigeti, O. (2012): Közösségi marketing az élelmiszer-gazdaságban. In: Szakály, Z., Szente, V. (2012, szerk.): Agrártermékek közvetlen értékesítése, marketingje. Szaktudás Kiadó, Budapest, 2012, 16-29. o.

15. Szente, V., Torma, D. (2015): Organic Food Purchase Habits in Hungary. Journal of Economic Development, Environment and People Volume 4, Issue 1, 2015.

\section{Jogszabályok}

- 36/2014. (XII. 17.) FM rendelet az élelmiszerekkel kapcsolatos tájékoztatásról.

- 52/2010. (IV. 30.) FVM rendelet a kistermelői élelmiszer-termelés, -előállítás és értékesítés feltételeiről.

- A Bizottság 1337/2013/EU végrehajtási rendelete (2013. december 13.) az 1169/2011/EU európai parlamenti és tanácsi rendelet alkalmazási szabályainak a friss, hütött vagy fagyasztott sertés-, juh-, kecske- és baromfihús származási országa vagy eredete helyének feltüntetése tekintetében történő megállapításáról.

- A Bizottság 2008. szeptember 5-i 889/2008/EK rendelete az ökológiai termelés, a címkézés és az ellenőrzés tekintetében az ökológiai termelésről és az ökológiai termékek címkézéséről szóló 834/2007/EK rendelet részletes végrehajtási szabályainak megállapításáról

- Az Európai Parlament és a Tanács 1169/2011/EU rendelete (2011. október 25.) a fogyasztók élelmiszerekkel kapcsolatos tájékoztatásáról. 